\title{
Ellipsomyxa gobii gen. et sp. n. (Myxozoa: Ceratomyxidae) in the common goby Pomatoschistus microps (Teleostei: Gobiidae) from Denmark
}

\author{
Marianne Køie \\ Marine Biological Laboratory, University of Copenhagen, DK-3000 Helsingør, Denmark
}

Key words: Ellipsomyxa gobii, Myxozoa, Pomatoschistus microps, Denmark

\begin{abstract}
A new myxosporean species Ellipsomyxa gobii gen. et sp. n. is described from the common goby Pomatoschistus microps (Krøyer) (Perciformes, Gobiidae). Plasmodia with long branched pseudopodia in the gallbladder develop to subspherical bisporous plasmodia. The myxospores were found in the gallbladder, and the hepatic and bile ducts. The new genus is characterised by the morphology of the myxospores. The myxospores have smooth thin valves elongated in the direction perpendicular to the plane of the straight central transverse indistinct sutural line. The two spherical polar capsules open some distance from the sutural line on opposite sides. The new genus thereby differs from Leptotheca Thélohan, 1895. Ellipsomyxa gobii is tentatively placed in the Ceratomyxidae.
\end{abstract}

Examination of myxozoans in marine fish in Denmark revealed a previously undetected myxosporean species in the gallbladder of the common goby Pomatoschistus microps (Krøyer) (Gobiidae). Pomatoschistus microps is the most common goby in shallow areas on sandy or muddy shores in Denmark. It often occurs in intertidal and brakish areas. It is replaced by the sand goby Pomatoschistus minutus (Pallas) on sandy bottom at greater depths. The new myxozoan species is compared with previously described myxozoan species.

\section{MATERIALS AND METHODS}

In total 100 specimens of the common goby Pomatoschistus microps (Krøyer, 1838) were collected in the North harbour of Helsingør in May-July 2003, and 100 P. microps (size range $3.0-5.5 \mathrm{~cm}$ long) were collected in the Nivå Bay, the Øresund, between Helsingør and Copenhagen in June-August 2001. The depths were between 0.2 and $0.5 \mathrm{~m}$ and the salinity between 10 and $15 \%$. The specimens were examined immediately upon capture. The body cavity of gobies was opened from the anal opening to the gills and the internal organs were examined using a dissecting microscope. Fresh smears of various parts of the fish were compressed between the slide and coverslip. Fresh smears were made of urine, urinary bladder wall, various parts of the digestive tract, kidney, bile, gallbladder wall, liver, gills and musculature. Some smears were air-dried, methanol-fixed, stained with Giemsa and embedded in DPX. Measurements are based on fresh smears and are given as the mean and range $(\mathrm{n}=$ $10)$.

\section{RESULTS}

The examination using the dissecting microscope did not reveal the presence of myxozoans. Smears of the gallbladder wall, bile and liver with hepatic ducts revealed small ellipsoid myxospores (Figs. 1, 5-7). The ellipsoid myxospores were found in $45 \%$ of Pomatoschistus microps collected in the North harbour of Helsingør and in $6 \%$ of $P$. microps collected in the Nivå Bay. No other visceral tissues harboured myxospores and the gallbladder myxosporean species was the only myxozoan species found.

Plasmodia with long pointed and branched pseudopodia were attached to the internal gallbladder wall (Figs. 2, 3). These plasmodia later transformed into free bisporous plasmodia. The plasmodia in the gallbladder lumen with concentrated bile were smaller than those found in the hepatic ducts. Subspherical smooth plasmodia, sometimes with one or more short pseudopodium-like outgrowths, were found in the gallbladder and bile duct (Fig. 4).

\section{Ellipsomyxa gen. n.}

Diagnosis. Ellipsoid myxospores elongated in direction perpendicular to the plane of straight central transverse sutural line. Thin-walled valves elongate or hemispherical. In apical or polar view, two equal-sized spherical polar capsules occur on longitudinal axis some distance from sutural line and opposite ends. In lateral view, polar capsules occur close to surface at opposite sides. Axes of polar filaments parallel to sutural line. Polar capsules discharge at opposite sides. Capsular foramina between sutural line and opposite sides. Myxospores develop in bisporous plasmodia. Type and only species: Ellipsomyxa gobii sp. n.

E t y m o log y: The generic name relates to the shape of the myxospore.

Taxonomic affinities: The genus is tentatively placed in the Ceratomyxidae Doflein, 1899. 

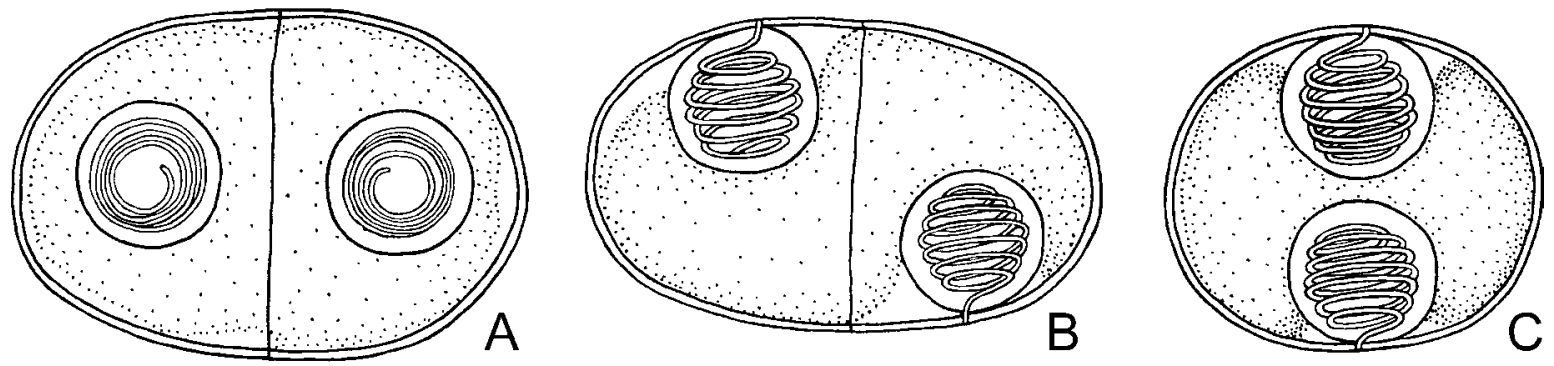

Fig. 1. Ellipsomyxa gobii sp. n., myxospore. A - apical or polar view; B - lateral view; $\mathrm{C}-$ frontal view. Scale bar $=5 \mu \mathrm{m}$.
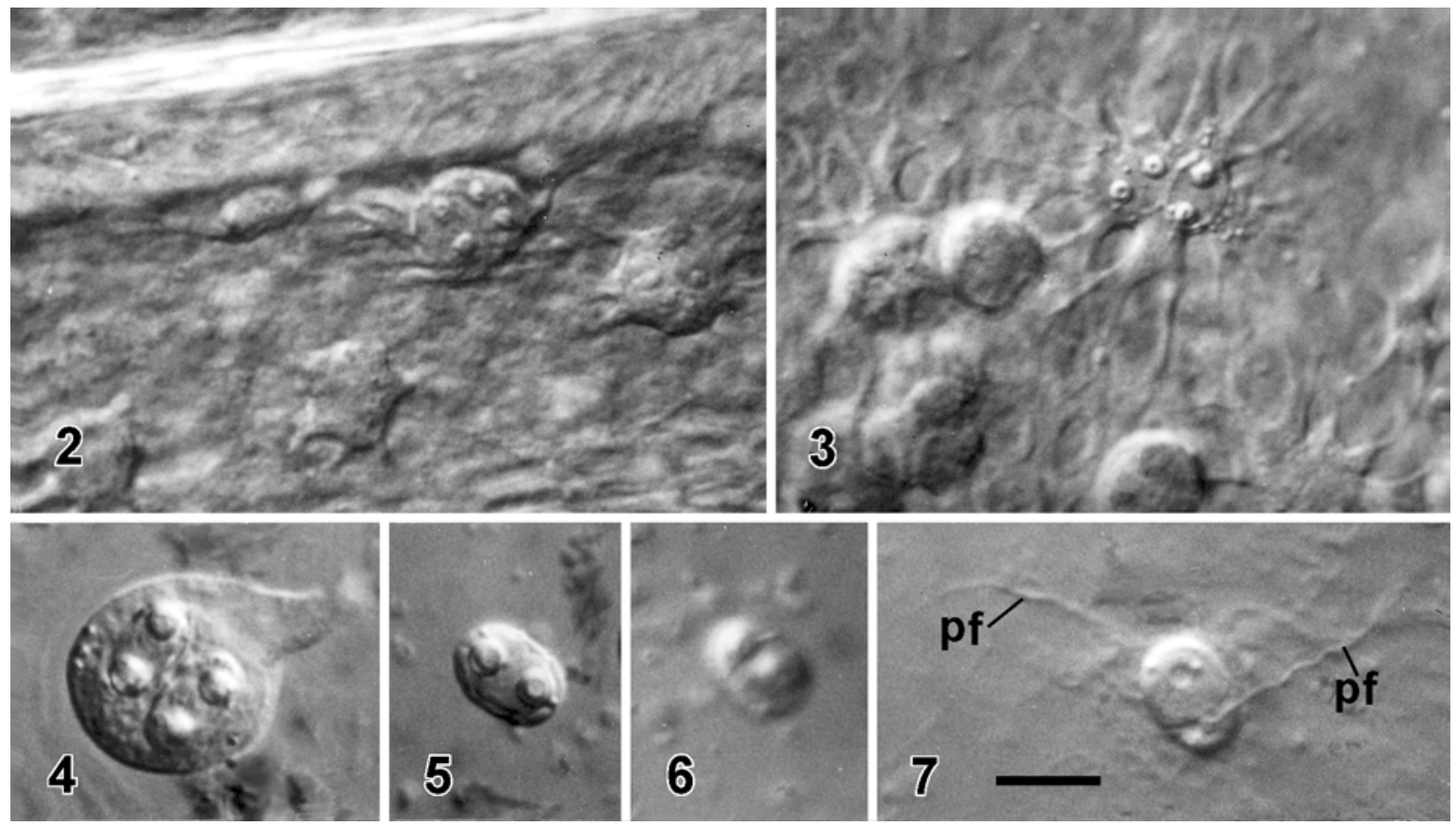

Figs. 2-7. Different developmental stages of live Ellipsomyxa gobii sp. n. in Pomatoschistus microps. Interference contrast. Fig. 2. Fresh squash preparation of the gallbladder including the gallbladder wall with attached plasmodia. Fig. 3. Stellar plasmodia at various developmental stages on the internal gallbladder wall and free young subspherical plasmodia. Fig. 4. Bisporous plasmodium. Fig. 5. Myxospore seen in apical view. Fig. 6. Myxospore focused at the sutural line. Fig. 7. Myxospore with extruded filaments. pf - polar filament. All to same scale; scale bar $=10 \mu \mathrm{m}$.

\section{Ellipsomyxa gobii sp. n.}

Figs. 1-7

With characters of the genus. Myxospores (Figs. 1, 57) ellipsoid, 7.0 (6.6-7.5) $\mu \mathrm{m}$ long, $8.7(8.0-9.0) \mu \mathrm{m}$ wide and $11.6(10.8-12.0) \mu \mathrm{m}$ thick. Two thin-walled valves perpendicular to transverse indistinct sutural line. Valves sometimes slightly asymmetrical. Spores slightly oval in frontal view. Spherical polar capsules $3.1(3.0-3.2) \mu \mathrm{m}$ in diameter, distance between polar capsules 2.7 (2.4-3.0) $\mu \mathrm{m}$. Polar capsules open $2.9(2.7-3.1) \mu \mathrm{m}$ from sutural line at opposite sides. Polar filaments coiled 6-7 times. Maximum length of extruded polar filaments $40 \mu \mathrm{m}$. Polar capsules after extrusion of polar filament $2.0(1.8-2.2) \mu \mathrm{m}$ in diameter. Distance between empty capsules 3.7 (3.34.2) $\mu \mathrm{m}$. Sporoplasm fills spore cavity completely. Nuclei not distinct. Subspherical bisporous plasmodia (Fig. 4) measured $19(16-23) \times 16(13-20) \mu \mathrm{m}$. 
Ty pe and only known host: Pomatoschistus microps (Krøyer, 1838) (common goby) (Perciformes, Gobiidae).

T y p e 1 o c a 1 i t y : The Nivå Bay, the Øresund, Denmark $\left(55^{\circ} 55^{\prime} \mathrm{N}, 12^{\circ} 31^{\prime} \mathrm{E}\right)$.

Site of infection: Gallbladder wall and lumen, hepatic and bile ducts.

Preva 1 e n c e : $6 \%$ (Nivå Bay) and 45\% (the North harbour of Helsingør) of P. microps (3.0-5.5 cm long).

Ty pe materia 1: Slides with stained spores are deposited in the Institute of Parasitology, Academy of Sciences of the Czech Republic, České Budejovice (Cat. nos. DPF-002 to DPF-006) and in the Zoological Museum, Copenhagen, Denmark.

E t y m o lo g y: The specific name was derived from the common name of the fish host (common goby).

Host reaction. No signs of inflammatory reaction were detected in any stage of infection. No differences in appearance of uninfected and infected livers and gallbladders were found.

\section{DISCUSSION}

The dimensions and morphology of this parasite does not fit the description of any species of any known myxozoan genus. Ellipsomyxa gobii is tentatively placed in the family Ceratomyxidae. It differs from most members of the Ceratomyxidae by not having the polar capsules close to the sutural line in a plane perpendicular to it (Lom and Dyková 1992). Ellipsomyxa is most similar to Leptotheca Thélohan, 1895 because the spores have the largest axis perpendicular to the sutural plane and because the thin shell-valves do not exceed the axial diameter of the spore. However, the capsular foramina of E. gobii occur at opposite sides of the spore and some distance from the sutural line, whereas in Leptotheca they occur close to each other and close to the sutural line. Leptotheca fusiformis Davis, 1917 is similar to the present species in that the openings of the polar capsules occur on opposite sides of the spore (Davis 1917). Leptotheca fusiformis was described from the bile of a hammer-head shark Cestracion zygaena and most likely belongs to the same genus as the present species.

\section{REFERENCES}

DAVIS H.S. 1917: Myxosporidia of the Beaufort region, a systematic and biological study. Bull. Bur. Fish., Wash. 35: 203-243.
LOM J., DYKOVÁ I. 1992: Protozoan Parasites of Fishes. Development in Aquaculture and Fisheries Sciences 26. Elsevier, Amsterdam, 315 pp.

Accepted 16 October 2003 